\title{
DRAWING THE CAUSE OF SOCIAL CONFLICT IN PEMILUKADA
}

\author{
Nadya Kharima \\ Syarif Hidayatullah State Islamic University of Jakarta \\ Email: nadya.kharima@gmail.com
}

Received: $8^{\text {th }}$ March 2018; Revised: $15^{\text {th }}$ April 2018; Accepted: $19^{\text {th }}$ June 2018

\begin{abstract}
The rise of social conflicts generated in Pemilukada in different ways need an anticipated measure. If the problems continue to increase, Social Development Goals such as community development is difficult to realize while public will only be a victim. In this regard, this article intends to explore a case of social conflict during Pemilukada in Palopo City. This means understanding the causes of the emergence of social conflicts exists in during Pemilukada. Utilizing a qualitative research approach with exploration methods based on available sources, the analysis is performed by linking the existing conflict theory with the results of interviews and observations of the author. Findings indicates three points generating the emergence of social conflict, where each of them have a deterrent social conflict in Pemilukada.
\end{abstract}

Keywords: pemilukada, social conflict, social development goals.

Abstrak. Maraknya konflik sosial yang ditimbulkan dalam pemilukada di berbagai daerah sudah seharusnya dapat diantisipasi secara lebih baik. Karena jika masalah sosial ini terus mengalami peningkatan maka salah satu tujuan dari pembangunan sosial yaitu pengembangan masyarakat justru tidak akan terwujud karena masyarakat hanya akan menjadi korban dari konflik yang telah terjadi selama pemilukada berlangsung. Karena itu, penulis mencoba untuk melakukan penelitian berdasarkan salah satu kasus konflik sosial yang telah terjadi pada pemilukada yaitu di Kota Palopo. Berkaca dari konflik sosial yang terjadi dalam pemilukada di Kota Palopo, penulis mencoba menakar apa saja penyebab dari munculnya konflik sosial yang ada dalam pemilukada. Dengan menggunakan teknik penelitian kualitatif dengan metode ekplorasi berdasarkan sumbersumber yang ada. Kemudian analisa dilakukan dengan menghubungkan antara teori konflik yang ada dengan hasil wawancara dan pengamatan penulis. Di mana dari analisa penulis telah ditemukan tiga hal yang menjadi penyebab dari munculnya konflik sosial, masing-masing dari ketiganya ini juga dapat menjadi pencegah terjadinya konflik sosial dalam pemilukada.

Kata Kunci: pemilu kada, konflik sosial, pembangunan sosial. 


\section{Preface}

The Indonesian state embodies the spirit of democracy by holding General Elections of Regional Heads and Deputy Regional Heads abbreviated as pemilukada atau pilkada. This event is carried out directly as a form of democracy which is interpreted as "from the people, by the people, and for the people". Since 1998, Indonesia has developed a competitive and dynamic democratic system in which the election of leaders is a matter of forming a government on the will of the people expressed through voting.

Therefore, pemilukada directly provide ample room for democratic learning at the local (regional) level. As an arena of learning democracy, direct regional head elections are expected to bring many benefits to the development of democracy, regional governance, and the performance of political institutions in the area (Rully Chairul Azwar, 2007).

But in fact, the direct election system on the other hand is the potential for the emergence of conflicts of interest between various elements of society, especially among local elites in the region. The direct implementation of the elections turned out to show high dynamics. In addition to the success in presenting regional leaders, direct local elections have also been decorated with the reality of social conflicts that occur in many areas (Suharizal, 2011).

If reflecting on the post-conflict local election throughout 2005-2011, the potential for conflict is increasing. Several regions experienced riots due to postconflict local elections including Humbang Hasudutan, Mojokerto, Toraja, Soppeng and Bima. The Pemilukada in North Maluku the conflict was only completed after 1.5 years. Even the post-conflict local election in Puncak Regency, Papua, killed 19 people.

Other data obtained by the International Crisis Group (ICG), the number of violence that occurred in 224 scheduled post-conflict local elections in 2010 did not reach 10 percent. But this alone is an increase from the previous round. A study found that there were 13 cases of post-conflict local election violence that took place from 2005 to 2008. In 2010 alone, there were at least 20 cases recorded.

Conflicts of interests or political conflicts are now turning into social conflicts because those affected by the conflict in the post-conflict local elections ultimately lead to the community because of the many conflicts that have occurred, those affected and the perpetrators of the conflict itself are the community.

Contestation in the struggle for power at the local level is dominated by cases of conflict during the execution of direct elections, which is an antithesis of the ways of 
democracy in choosing a leader.

The latest is the issue of social conflict that occurred in the post-conflict local election in Palopo City, South Sulawesi. Riots occur when vote counting is conducted. Initially, the recapitulation process for the vote counting held by the Palopo City Election Commission in his office was conducive. However, due to allegations of vote inflation after the vote count was completed, supporters of the candidate pair began to rampage and throw stones and Molotov cocktails. The conflict was unavoidable and there were riots in Palopo City which resulted in government and non-government buildings being burned down by the mob.

The phenomenon of social conflict is like an iceberg. Behind the violence in conflict is stored accumulation of problems that are very complex and not handled seriously. Potential conflicts that are not managed properly can increase escalatively and can "explode" like a time bomb like what happened in Palopo City.

Therefore, understanding the root causes of conflict and identifying policies that can reduce the potential for conflict are very important to improve human development and eradicate existing social problems. It is very important to understand the causes of conflict, given the many political conflicts that occur in the world today. There is no community that escapes the conflict no matter how small, including political protest, violence with violence and civil chaos here and there. At a low level, such conflicts do not cause serious chaos in development.

Looking at the above issue, this journal was conducted with the intention to analyze the causes of social conflicts that arise in the community in the post-conflict local election (Regional Head General Election) by taking a sample of the Pemilukada of Palopo City. Researchers want social conflict in this post-conflict local election to be identified by understanding how social conflict can occur and how to deal with it more accurately. So that in the future, the community will better understand how social conflict can be overcome properly and what is even better is to avoid the occurrence of social conflicts in each post-conflict local election.

\section{Research Methods}

The method used in this journal research is to use qualitative research methods. Where qualitative research is a method for exploring and understanding meanings which - by a number of individuals or groups of people - are thought to originate from social or humanitarian problems. This qualitative research process involves important efforts such as asking questions and procedures, collecting specific data 
from participants, analyzing data inductively from themes specific to general themes, and interpreting the meaning of data.

The final report for this study has a flexible structure or framework. Whoever is involved in this form of research must apply a research perspective that is inductive in style, focuses on individual meaning, and translates the complexity of a problem (adapted from Creswell, 2007). Therefore, this qualitative approach is chosen by researchers based on research objectives that want to identify the problems of social conflict in the election as a form of evaluation of the effectiveness of election supervision.

Where to get the results of this study, researchers get the data needed through data findings in the field by searching for existing data, namely the authors collect data relating to the problems that the author discussed. In addition, the researcher carried out research by outlining the facts that happened naturally by describing the overall activities carried out through a field approach, in which intensive data and information collection efforts were accompanied by analysis and re-testing of all that had been collected.

\section{Discussion}

The emergence of this conflict was not expected before because according to the Chairperson of the Election Supervisory Committee of Palopo City, Hisma Kahman, there had never been a conflict because Palopo City was the kingdom's territory, the Luwu kingdom. Respect for others is very high. Palopo Pos journalist, Irfan Khaeruddin also added that in Palopo City conflict had never appeared, especially in post-conflict local elections. Because the previous election there was no conflict.

Starting from the holding of a democratic party for the people of Palopo City to elect the mayor and deputy mayor of Palopo City for the 2013 term until 2014. Nine pairs of mayor and deputy mayor candidates in Palopo City participated in the Palopo City election held on January 22, 2013. Finally the process The results of the first round of recapitulation of the votes of the Palopo City Election held on January 27, 2013 had led to a decision. In the KPU Palopo open plenary meeting at the Palopo KPU office, according to the results of the vote recapitulation, it was known that there were no nine pairs of candidates for mayor and deputy mayor of Palopo City who were above 30 percent. The Palopo City KPU decided to conduct the second round of post-conflict local election.

So it was decided pair number 5, Haidir Basir-Thamrin Jufri (HATI) which was carried by the PKS, PPP, PKB, PKPB, and Democratic Party coalition and pair number 
1, Judas Amir-Akhmad Syarifuddin (JA) supported by the PDP coalition, PNBK, PPDI, Kedaulatan, Gerindra, PPD, and the Golkar Party are set to advance in the second round of the Palopo Election which will be held on March 27, 2013.

This is where the conflict finally happens, precisely after the voting of the second round of the Regional General Election of Palopo. According to the Chairperson of Panwaslukada, Hisma Kahman that during the vote counting day there had been no conflict. The conflict happened after the election precisely when the recap at the PPK level. The conflict was preceded by an indication that one of the supporters of the HATI candidate pair said there was an alleged vote bubble for one of the other candidate pairs on March 29, 2013.

When the vote count continued at the PPK level, the masses refused to do the calculations and they started burning with Molotov cocktails so the Wara Timur PPK did not have time to do the calculations even though it had already been opened. Even after the recap at the Palopo Election Commission level and the chosen pair was determined. Based on the results of the plenary commission of the General Election Commission of Palopo City, the pair number 1 (JA) received 37,469 votes (50.50\%) while the pair number 5 (HEART) 36,731 (49.50\%), the difference of 738 votes. Thus, the JA pair (HM. Judas Amir - Akhmad Syarifuddin Daud) was appointed as the winner in the General Election of Mayor and Deputy Mayor of Palopo 2013-2018.

Witnesses from the HATI team did not accept the results of the plenary and did not want to sign the results of the plenary so that the arson began. Whereas Mass is a match of the second round winner, Judas Amir-Ahmad Syarifuddin (JA) whose numbers are almost the same as the mass number five throwing Molotov cocktails and using other objects.

Eventually the mob stormed into the courtyard of the Golkar Party office just to stone the office. The glass in front of the office broke. After throwing stones, the masses who were getting hot burned the office. The police several times threw tear gas at the masses.

In addition to the Golkar office, the mob also destroyed the Palopo Mayor's Office. In fact, the Regional Civil Service Agency (BKD) section of the Palopo Mayor's Office has also been burned by the masses. Two official vehicles parked in the courtyard of the mayor's office were also targeted. They destroyed two official cars and one motorbike.

In a separate place, hundreds of traders in Palopo Central Market rushed to evacuate their merchandise to a safe place. Because there is a mass issue, it will also burn the central market. "There is a short message the market will also be burned," 
said Eri, one of the traders. This is where social conflict is increasingly felt, because at that time it was no longer a mass of supporters, the community was finally made anxious and panicked. The economy, education and all the activities of the people in Palopo City were stopped.

And for its handling, Palopo District police were backed up by three neighboring police stations and the 721 Kodim, including the Baebunta Mobile Brigade. Security forces appeal to the masses to remain calm. Where in this incident one person was secured by the police for allegedly being a provocateur. Until 16.00 WITA, Palopo was conducive.

After the conflict nothing else is done. Still according to Irfan, that until the interview was conducted there was no rehabilitation process carried out. It's just that Palopo Police had mediated between the two parties, namely the mass supporters of each candidate pair Mayor and Deputy Mayor Palopo. The police party reconciled two camps of the candidate for the mayor who had fought during the second round of regional elections. This peace was carried out because he was worried that one of the teams would stir again when the Constitutional Court (MK) decided the winner in the Palopo City Election dispute.

\section{Analysis}

In theory what happened in Palopo City can already be identified as a conflict according to Robert Ted Gurr (1980). Understanding of conflict with elements of violence, one of which was stated by Robert Ted Gurr. According to him so that a social relationship can be called a conflict, then at least it must fulfill four characteristics (Robert Gurr, 1980: 2). These four characteristics are:

\section{There are two or more parties involved}

Based on the sequence of events it is clear that there are more than one party involved in social conflict in the Pemilukada of Palopo City. Beginning with a difference of opinion between one of the supporters of the candidate pair and the election organizers, both the KPU and the Panwaslukada related to the alleged inflation of ballots carried out by KPPS in several polling stations in Palopo City.

\section{They are involved in acts that are hostile to each other}

The clash between supporters of the Mayor and Deputy Mayor Palopo's candidate pair is clear that there is an attitude of hostility towards each other which causes stone throwing and burning of one of the party bearers of one of the candidate pairs. The 
rival mass of the second round winner, Judas Amir-Ahmad Syarifuddin (JA), whose numbers were almost the same as the number five mass, who threw Molotov cocktails and used other objects, was successfully repelled by security forces.

\section{They use acts of violence that aim to destroy, injure, and obstruct their opponents.}

Supporters of candidates for Mayor and Deputy Mayor pairs who lost their arson as acts of frustration over the defeat they received. The crowd of more than 500 people came and immediately threw and burned. A few moments when the mass of the two candidate pairs threw one another, a fire suddenly appeared from the Palopo Mayor's office.

\section{These conflicting interactions are open so they can be detected easily by independent observers.}

Clashes between supporters and arson at several points in open spaces in the sense that they can be seen by the public or the public in Palopo City. Moreover, one of the buildings namely the Palopo Mayor building which is a public facility was deliberately burned by a raging mob.

After a brief description of the occurrence of social conflict in the post-conflict local election in the City of Palopo, the following is an analysis of the causes of conflicts that have been compiled by the authors based on the findings obtained:

\section{Party Elites (Candidate Pair)}

The unpreparedness of the candidate pair to accept defeat becomes the main source of the cause of the emergence of social conflict, where this conflict is used to bring down one of the other candidate pairs. This conflict arose when at the end of the phase of the election in Palopo City, when the vote count was carried out at the PPK level. When it comes to knowing that the candidate pair who is favored suffered a defeat then begins to make the alleged issue of balloting. With the results issued by the Palopo City Election Commission, one candidate pair felt aggrieved over the results of the recapitulation.

Like the last case in Palopo, Perludem's Executive Director, Titi Anggraini as the election observer added that the conflict usually begins because of the lack of satisfaction of the candidate pairs or political parties of the candidate pair. It also happens because there are those who are not ready or not satisfied with the organizer. More because election participants or candidate pairs, or even political investors are 
not satisfied because the candidates lose.

Titi emphasized that conflicts that have an impact on violence or riots always occur when determining outcomes, there are also those who are nominated. So the outlook is always on two, namely nominating and escaping or not qualifying. Well, if the outcome of the conflict then happens, then everything is an elite problem, there is no one because the voters are not good and then burnt down, it always involves the elite or candidate pair actors.

\section{Government Apparatus (Election Organizers, Regional Governments and Security Parties)}

Chairman of the Election Supervisory Body (Bawaslu), Muhammad who also went directly in dealing with post-conflict local election conflict in Palopo City said that in each post-conflict local election there should be good coordination between organizers, election participants and local governments, coordination in order to try to coordinate and identify potential conflict and potential problems in each Kada Election in order to avoid wider post-conflict local election conflict.

In his observation, Muhammad confirmed that the Palopo election was due to the lack of good coordination between the organizers, the regional government and the election participants or the candidate pairs. So that there are things that are perceived by the candidate pair as a violation, but the KPU is considered as not a violation. So that the accumulation of differences in perception gave rise to distrust by the election organizers.

Resort Chief of Palopo Resort, Adjunct Senior Commissioner Endang Rasyidin admitted that he was cheated because officers concentrated on KPU. Endang said that the masses who were not satisfied with the results of Pilwalkot should follow the existing process and Palopo was on standby one. Chairperson of Palopo City Panwaslukada, Hisma also said that the emergence of this conflict was also the result of weak police, where each couple should not only be given a strict escort but also the police could get inside information about what activities would be carried out by the candidate pair including desire to burn.

The absence of detection of the question of the burning will be impossible according to Hisma, so it can be said that the police are careless and this is a big problem. The police precisely focus on guarding the plenary decision of the results of the second round of recapitulation of the votes of the Palopo City election. So it is only natural that the KPU Building is safe from the mass rage, but the surrounding buildings 
that are not under guard actually become the raging mass of the masses.

In line with the Regional Election Supervisory Committee of Palopo City, Palopo Pos reporter admitted that the police should be able to coordinate with intelligence services. Moreover, according to Irfan, the signal that emerged was two days that had exploded, before that it had happened in the kelurahan, then in the sub-district, then later in the City.

\section{Society}

Various kinds of issues were spread both to the public and the press so that the conflict could no longer be avoided. Chairperson of Palopo City Panwaslukada, Hisma Kahman who is also a local indigenous community, said that in fact the community factor also existed, there were many issues which made the motives of mistrust to the organizers that caused the conflict. In this case the Palopo community is said to be very easy to believe in the existence of fraudulent issues carried out by the Palopo City Election Commission to win one candidate pair. The community does not first look for the root of the problem.

It was explained by a senior Kompas journalist, Sidik Pramono that the conflict occurred partly because of the gap in political understanding among lay people with elites who controlled information, networks, and especially capital. The interests of the elites that are not fulfilled in the election contestation, encourage them to use the masses to be a pressure tool so they can only use existing issues to build the goal of creating conflict. Also added by Sidik, that a less mature society can also be the cause of the emergence of conflict so that it is easy to mobilize for mass amok. Especially if the mobilization is then driven by money, it will become even worse.

Social conflict in post-conflict local elections is essentially a political learning for the people. The interests of the people must be prioritized. The people should not be trapped on the brink of political conflict which is actually just an illusion of personal interest from the political elites who play. The people must be directed to awareness of how to understand and understand the conflict itself. Later, the people will be able to objectively evaluate which ones really fight for the people's fate, which ones are fair play and which ones are manipulative. Conflict is no longer taboo to be found, so that in the end the people can automatically prevent conflicts.

The three things that play an important role are party elites or candidate pairs, government and society. All three can be a cause, but can also be a deterrent to conflict. Where after the conflict the three must carry out their social functions in a positive 
direction. Where according to Coser, conflict can be positively or negatively functional. Functionally positive if the conflict has the effect of strengthening the group, the opposite is negative if it moves against the structure. In relation to the value system that exists in society, conflict is functionally negative when attacking a core value.

More specifically, conflict can function as a positive factor ("supporter") and negative factor ("destroyer") for social peace capital. Positive, conflict can function as a driver of the growth of social peace capital. As stated by Parson, Jorgensen and Hernandez (1994: 261), conflict can increase group cohesiveness, raise hidden issues and expectations, clarify group boundaries and norms, and reinforce the objectives to be achieved. However, conflict can also be destructive of group integrity and social integration of society on a wider scale. If it goes beyond the limits of tolerance and the capacity of the parties involved and no solution is immediately sought, the conflict can lead to social "peace".

\section{Conclusion}

There are three factors that cause social conflict in post-conflict local elections, namely party elites or candidate pairs, the government as the organizer and the community itself. All three are inseparable from the occurrence of social conflict, therefore there must be awareness and continuity that is closely intertwined between the three. Where these three can not only be a cause, but can also be a deterrent to the emergence of social conflict. This will happen if all three really prioritize the realization of good democracy, not because of the interests of each group.

\section{Bibliography}

Azwar, Rully Chairul. (2007). Partai Politik, Pilkada dan Media Massa. Jurnal Konstitusi Volume 4 Nomor 1. Maret.

Creswell, John W. (2012). Research Design Pendekatan Kualitatif, Kuantitatif dan Mixed.

Yogyakarta: Pustaka Pelajar.

Gurr, Ted Robert (ed). (1980). Handbook of Political Conflict; Theory and Research. New York: The Free Press.

Parsons, Ruth J., James D. Jorgensen dan Santos H. Hernandez. (1994). The Integration of Social Work Practice. California: Brooks/Cole.

Suharizal. (2011). Pemilukada: Regulasi, Dinamika dan Konsep Mendatang. Jakarta: Raja Grafindo Persada. 